\title{
An Abnormality of the Gene that Encodes Neutrophil Fc Receptor III in a Patient with Systemic Lupus Erythematosus
}

\author{
Marcus R. Clark, Linda Liu, Sarah B. Clarkson, Peter A. Ory, and Ira M. Goldstein \\ Rosalind Russell Arthritis Research Laboratory, Department of Medicine, University of California, San Francisco, California 94143; \\ and the Medical Service, San Francisco General Hospital, San Francisco, California 94110
}

\begin{abstract}
In the course of examining the structure and function of Fc receptors on peripheral blood cells of patients with systemic lupus erythematosus, we identified a patient whose neutrophils did not react with either monoclonal or polyclonal antibodies to Fc receptor III. However, neutrophils from the patient were comparable to neutrophils from healthy controls with respect to their expression of Fc receptor II, complement receptor 1 , complement receptor 3 , and the phosphatidylinositol-linked, complement regulatory protein, decay-accelerating factor. The abnormality of expression of Fc receptor III was limited to the patient's neutrophils (her natural killer cells reacted normally with anti-Fc receptor III antibodies), and was associated with abnormal recognition and binding of IgG-coated erythrocytes. Analysis of genomic DNA revealed evidence that failure of the patient's neutrophils to express Fc receptor III was most likely due to an abnormality of the gene that encodes this receptor. (J. Clin. Invest. 1990. 86:341-346.) Key words: flow cytometry - natural killer cells • genomic DNA • Southern blot • polymerase chain reaction
\end{abstract}

\section{Introduction}

Three classes of receptors for the Fc regions of IgG immunoglobulins are expressed on the surfaces of human leukocytes $(1,2)$. One of these, Fc receptor III (Fcy RIII), ${ }^{1}$ is a glycoprotein that is expressed in a heterogeneous manner on the surfaces of human neutrophils, natural killer (NK) cells, and macrophages. Fc $\gamma$ RIII on neutrophils and Fc $\gamma$ RIII on NK cells differ with respect to their apparent molecular masses (3), and are products of distinct, but highly homologous, genes that are expressed in a cell-specific fashion (4). Two alleles (NA1 and

Address reprint requests to Dr. Ira M. Goldstein, Department of Medicine, Box 0868, University of California, San Francisco, CA 941430868.

Received for publication 23 February 1990 and in revised form 30 March 1990.

1. Abbreviations used in this paper: DAF, decay-accelerating factor; Fc $\gamma$ RIII, Fc receptor III; Fc $\gamma$ RII, Fc receptor II; NK cells, natural killer cells; PCR, polymerase chain reaction; PI, phosphatidylinositol; RBCs, erythrocytes; SLE, systemic lupus erythematosus.

J. Clin. Invest.

(c) The American Society for Clinical Investigation, Inc.

0021-9738/90/07/0341/06 \$2.00

Volume 86, July 1990, 341-346
NA2) of the gene that encodes neutrophil Fc $\gamma$ RIII account for the structural and antigenic polymorphism of this receptor (4-6). Both forms of neutrophil Fc $\gamma$ RIII are anchored to the cell membrane via a glycosyl linkage to phosphatidylinositol (PI) (4, 7-11), while the NK cell receptor is a transmembrane protein $(4,9-11)$. Macrophage Fc $\gamma$ RIII presumably is identical to NK cell Fc $\gamma$ RIII (4).

Fc $\gamma$ RIII mediates binding of IgG-coated particles to phagocytic cells in vitro $(1,2)$, and probably facilitates clearance of circulating immune complexes by tissue macrophages in vivo (12). Indeed, previous studies have shown that Fc $\gamma$ RIII mediates the removal of IgG-coated erythrocytes (RBCs) from the circulation of chimpanzees (12) as well as the removal of IgGcoated platelets from the circulation of humans (13).

In this report, we describe a patient with systemic lupus erythematosus (SLE) whose neutrophils are not recognized by either monoclonal or polyclonal antibodies to Fc $\gamma$ RIII, but react normally with antibodies to Fc receptor II (Fc $\gamma \mathrm{RII})$, as well as with antibodies to complement receptor 1 , complement receptor 3, and the PI-linked, complement regulatory protein, decay-accelerating factor (DAF). Abnormal expression of Fc $\gamma$ RIII is limited to the patient's neutrophils, is associated with abnormal recognition and binding by these cells of IgGcoated RBCs, and appears to be due to an abnormality of the gene that encodes this receptor.

\section{Methods}

Flow cytometry. Procedures involving human subjects were approved by the Committee on Human Research at the University of California, San Francisco. Neutrophils and mononuclear leukocytes were isolated from venous blood of patients with SLE and healthy volunteers as described previously (14). Cells were incubated with control proteins or antibodies, and then stained with FITC-conjugated goat, antimouse, or anti-human IgG and IgM (Jackson Immunoresearch Laboratories, Avondale, PA). Samples were subsequently examined by flow cytometry using a Cytofluorograph II (Ortho Diagnostic Systems Inc., Westwood, MA).

The anti-Fc $\gamma$ RIII MAb, $3 \mathrm{G} 8$ (murine $\mathrm{IgG}_{1}$ ) (15), was a generous gift of Dr. Jay Unkeless (Mount Sinai Medical Center, New York). The anti-Fc $\gamma$ RIII MAb, Leu 11b (IgM) (16), was obtained from Becton Dickinson \& Co., Mountain View, CA. The anti-Fc $\gamma$ RII MAb, IV.3 (murine $\mathrm{IgG}_{2 \mathrm{~b}}$ ) (17), was obtained from Dr. John Looney, University of Rochester, Rochester, NY. MAb IA10 (murine $\mathrm{IgG}_{2 \mathrm{a}}$ ) (18) to DAF was a generous gift of Dr. Ingrid Caras, Genentech Inc., South San Francisco, CA. MAbs to complement receptor 1 (YZ-1, murine $\mathrm{IgG}_{1}$ ) (19) and complement receptor 3 (IB4, murine $\mathrm{IgG}_{2 \mathrm{a}}$ ) (20) were obtained from Dr. Richard Jack, Harvard Medical School, Boston, MA, and Dr. Samuel Wright, The Rockefeller University, New York, respectively. The cell line producing MOPC 21 (murine IgG $_{1}$ myeloma) 
was obtained from American Type Culture Collection, Rockville, MD. RPC 5 (murine $\mathrm{IgG}_{2 \mathrm{a}}$ myeloma), MOPC 11 (murine $\mathrm{IgG}_{2 \mathrm{~b}}$ myeloma), and TEPC 183 (murine IgM myeloma) were obtained from Bionetics Laboratory Products, Charleston, SC. Polyclonal anti-NA1 and antiNA2 alloantisera (21) were generously provided by Dr. Parviz Lalezari (Albert Einstein Medical Center, Bronx, NY).

Binding of IgG-coated RBCs to neutrophils. Sheep RBCs (Colorado Serum Co., Denver, CO) were coated with rabbit anti-sheep RBC IgG (diluted 1:15,000) (Cordis Laboratories Inc., Miami, FL), and then resuspended at a final concentration of $0.5 \%$ ( $(\mathrm{vol} / \mathrm{vol})$. Equal volumes of IgG-coated RBCs and either MAb 3G8 or the myeloma protein MOPC $21(50 \mu \mathrm{g} / \mathrm{ml})$ were added to neutrophils which were adherent to poly-L-lysine $(100 \mu \mathrm{g} / \mathrm{ml})$ (Sigma Chemical Co., St. Louis, MO)coated Terasaki plates (Miles Laboratories Inc., Naperville, IL). After 2 $h$ of incubation at $4^{\circ} \mathrm{C}$, unattached $\mathrm{RBCs}$ were removed by washing. Binding of IgG-coated RBCs to neutrophils was scored by phase-contrast microscopy.

Analyses of genomic DNA. Aliquots $(20 \mu \mathrm{g})$ of genomic DNA, prepared from peripheral blood mononuclear cells as described previously (22), were digested with either Eco RI, Hind III, or Bam HI (New England Biolabs, Beverly, MA), electrophoresed in agarose gels, blotted onto nylon membranes (GeneScreen Plus, New England Nuclear, Boston, MA), and probed as recommended by the manufacturer with a ${ }^{32} \mathrm{P}$-labeled fragment (bases 611-825, numbered according to Simmons and Seed [23]) of a cDNA which encodes the NAl form of neutrophil Fc $\gamma$ RIII (6).

To examine Fc $\gamma$ RIII gene-specific sequences in more detail, fragments of genomic DNA were amplified using the polymerase chain reaction (PCR) (24). Synthetic oligonucleotide primers were complementary to bases (611-625 and 805-825 of a corresponding cDNA) which flank a region of genomic DNA that contains two gene-specific restriction sites (4) (Fig. 1). The PCR was performed as described previously (24), using reagents from Perkin-Elmer (Norwalk, CT), 20 $\mu \mathrm{g}$ genomic DNA, $0.1 \mu \mathrm{mol}$ each of the oligonucleotide primers, 20 $\mu \mathrm{Ci}\left[{ }^{32} \mathrm{P}\right] \mathrm{dATP}$, and $2.5 \mathrm{U}$ Taq DNA polymerase. Aliquots of reaction mixtures subjected to 40 cycles of denaturation $\left(94^{\circ} \mathrm{C}\right.$ for $\left.2 \mathrm{~min}\right)$, annealing $\left(55^{\circ} \mathrm{C}\right.$ for $\left.2 \mathrm{~min}\right)$, and extension $\left(72^{\circ} \mathrm{C}\right.$ for $\left.3 \mathrm{~min}\right)$ were examined by PAGE and autoradiography before and after digestion with either Taq I or Dra I (New England Biolabs).

\section{Results}

Patient. E.W. is a 34-yr-old black woman with a 9-yr history of SLE. Clinically, she has had a cerebrovascular accident, glomerulonephritis, Raynaud's phenomenon, severe cutaneous vasculitis with lower extremity ulcers, and recurrent pleuritis. Laboratory abnormalities at the time she was initially studied included a Coomb's-positive anemia, antinuclear antibodies, and anti-DNA antibodies. Medications included chlorambucil (4 mg daily) and prednisone (15 mg daily). Her family history is remarkable only for a sister with an undefined inflammatory arthritis. Eight other siblings are alive and well.

Neutrophils from patient E.W. do not express normal $F c \gamma R I I I$. Shown in Fig. 2 are the results of a representative experiment in which neutrophils from patient E.W. and neutrophils from a healthy control donor were examined for their reactivity with the anti-Fc $\gamma$ RIII MAbs, $3 G 8$ and Leu $11 \mathrm{~b}$, and with the isotype-specific, control myeloma proteins MOPC 21 and TEPC 183. Reactivity of the patient's neutrophils did not exceed the background reactivity observed with the control myeloma proteins. In contrast, cells from the control donor reacted strongly with MAbs $3 G 8$ and Leu $11 \mathrm{~b}$. Similarly, reactivity of the patient's neutrophils with antibodies that recognize the NA1 and NA2 allotypic forms of neutrophil Fc $\gamma$ RIII did not reproducibly exceed that observed when cells were incubated with normal human serum. Cells from the control donor, however, reacted strongly with the anti-NA1 and antiNA2 alloantisera. It should be noted that neutrophils from all of the control donors examined, as well as neutrophils from eight other patients with SLE, reacted as expected with the anti-FcrRIII MAbs, 3G8 and Leu $11 \mathrm{~b}$, and with antisera directed against NA1 and/or NA2. In experiments not shown, neutrophils from patient E.W. were comparable to neutrophils from a healthy control donor with respect to their reactivity with MAbs to Fc $\gamma$ RII, complement receptor 1, and complement receptor 3 .

Consistent with our observations using flow cytometry, we were unable to immunoprecipitate Fc $\gamma$ RIII from lysates of surface-labeled neutrophils obtained from patient E.W. As described previously (5), Fc $\gamma$ RIII on neutrophils from a control appeared as a broad band from 50-70 kD after immunoprecipitation with MAb $3 G 8$ and SDS-PAGE. MAb 3G8, however, did not precipitate any labeled proteins from the patient's neutrophils (not shown).

Neutrophils from patient E.W. do not bind IgG-coated $R B C s$ normally. To determine whether failure of neutrophils from patient E.W. to express Fc $\gamma$ RIII was associated with
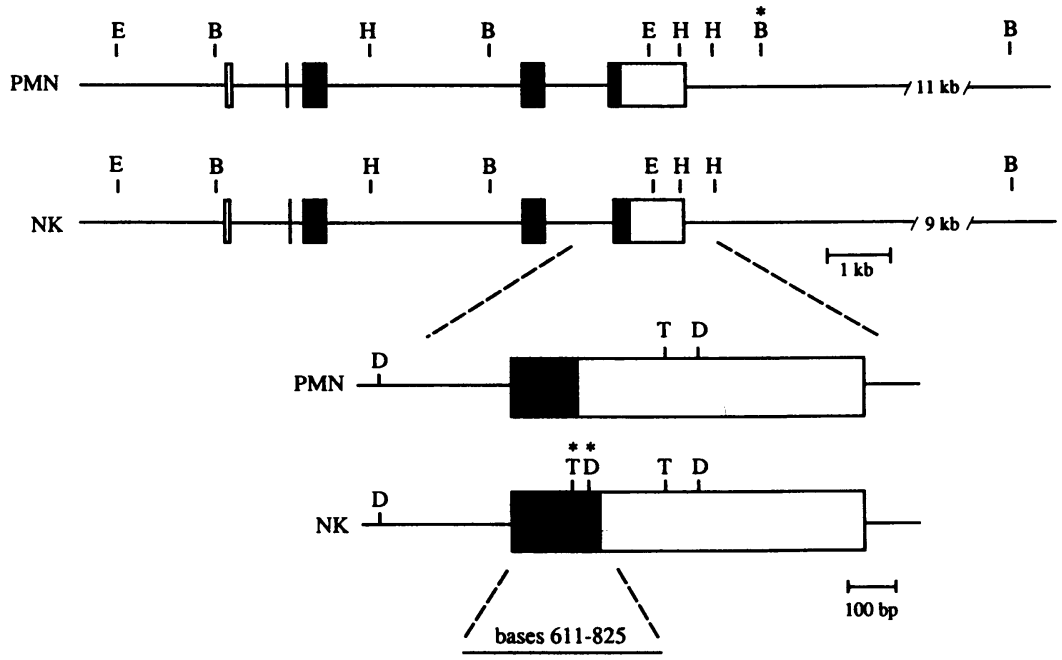

Figure 1. Organization of the genes that encode the neutrophil (PMN) and NK cell forms of FcyRIII (adapted from reference 4). The coding and noncoding regions of the genes are indicated by closed and open rectangles, respectively. Restriction sites are shown for Eco RI $(E)$, Bam HI $(B)$, Hind III $(H)$, Taq I $(T)$, and Dra I $(D)$. Gene-specific restriction sites are indicated with asterisks. Also shown is the region of the fifth exon that contains bases amplified in the PCR (bases 611-825). 


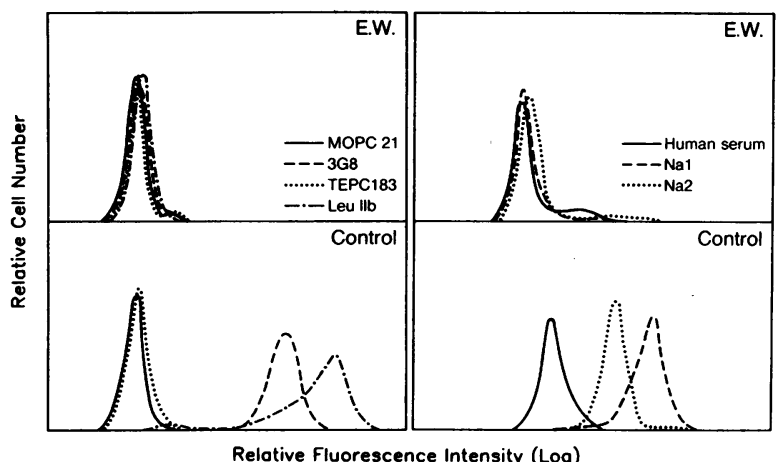

Figure 2. Neutrophils from patient E.W. do not react with antiFc $\gamma$ RIII antibodies. In the panel on the left, neutrophils from patient E.W. and neutrophils from a healthy control donor were examined by indirect immunofluorescence and flow cytometry for reactivity with the anti-Fcy RIII monoclonal antibodies, 3G8 and Leu 11b, and with the isotype-specific, control myeloma proteins, MOPC 21 and TEPC 183. In the panel on the right, neutrophils from patient E.W. and neutrophils from a control were examined for reactivity with antisera which recognize the NA1 and NA2 allotypic forms of neutrophil Fc $\gamma$ RIII, and with normal human serum. Results are expressed as relative fluorescence intensity (three-decade log scale) versus relative cell number, and are representative of those obtained in three additional experiments.

functional abnormalities, we examined the ability of her cells to recognize and bind IgG-coated RBCs. Adherent neutrophils were incubated at $4^{\circ} \mathrm{C}$ with IgG-coated sheep RBCs either in medium alone, in medium containing the myeloma protein, MOPC 21, or in medium containing MAb 3G8. The cells were then washed and examined by phase-contrast microscopy. In a representative experiment, individual neutrophils from a control donor bound an average of 5.4 IgG-coated RBCs in medium alone. This was unaffected in medium containing MOPC 21, but was reduced to 0.4 RBCs per neutrophil in medium containing MAb 3 G8 (which blocks ligand binding to Fc $\gamma$ RIII). In contrast, individual neutrophils from patient E.W. bound an average of only 0.9 IgG-coated RBCs in medium alone, and this number was not reduced further in medium containing MAb 3G8. Very similar results were obtained in three additional experiments performed with neutrophils from different control donors and with different preparations of IgG-coated RBCs. Thus, the patient's neutrophils are markedly impaired with respect to their ability to recognize and bind IgG-coated RBCs.

Neutrophils from patient $E$.W. express $D A F$. As indicated above, FcrRIII on human neutrophils is anchored to the plasma membrane via a glycosyl linkage to PI, as is the complement regulatory protein, DAF (7-12). Consequently, patients with paroxysmal nocturnal hemoglobinuria, a disorder in which anchoring of proteins to PI is defective (25), do not express normal amounts of either Fc $\gamma$ RIII or DAF on the surfaces of their neutrophils (7). To test the possibility that lack of expression of Fc $\gamma$ RIII on neutrophils from patient E.W. reflects a generalized abnormality involving the expression of proteins anchored to membranes via glycosyl-PI linkages, we examined her cells for the expression of DAF.

As shown in Fig. 3, neutrophils from patient E.W. were comparable to normal neutrophils with respect to their reactivity with an anti-DAF MAb. In experiments not shown, we

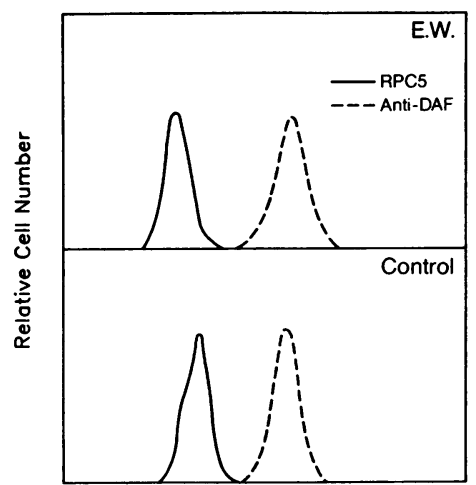

Relotive Fluorescence Intensity (Log)
Figure 3. Neutrophils from patient E.W. were comparable to normal neutrophils with respect to their reactivity with an anti-DAF MAb. The control myeloma protein used in these studies was RPC5. Results shown are representative of those obtained in one additional experiment.

found that the patient's mononuclear leukocytes also express DAF, as well as another PI-linked protein, CD14 (26). Thus, the lack of expression of Fc $\gamma$ RIII on neutrophils from patient E.W. is not the result of a generalized abnormality involving PI-linked membrane proteins.

Mononuclear leukocytes from patient E.W. express $F c \gamma R I I I$. In contrast to what we found when we examined her neutrophils, peripheral blood mononuclear cells from patient E.W. appeared to express Fc $\gamma$ RIII. As shown in Fig. 4, a small population of mononuclear leukocytes from patient E.W. (presumably NK cells) reacted with MAbs 3G8 and Leu 11b, as did a small population of mononuclear cells from a healthy control donor. Thus, only the patient's neutrophils fail to express Fc $\gamma$ RIII normally.

Analyses of genomic DNA. Normal human neutrophils constitutively synthesize Fc $\gamma$ RIII (27) and contain Fc $\gamma$ RIII transcripts $(4,6)$. When we examined RNA from neutrophils of patient E.W., however, we were unable to detect any material which hybridized with a 543-bp probe corresponding to the coding sequence of an Fc $\gamma$ RIII cDNA (23) (not shown). Since RNA from the patient's neutrophils did contain $\beta$-actin transcripts, these results suggested that the failure of her neutrophils to express Fc $\gamma$ RIII was due either to an abnormality of transcription or to an abnormality of the gene that encodes the receptor. Consequently, we turned our attention to an analysis of genomic DNA.

Digestion of genomic DNA from a healthy control and from patient E.W. with Eco RI and Hind III yielded identical fragments that hybridized with a probe corresponding to bases 611-825 of an Fc $\gamma$ RIII cDNA (Fig. 5). In contrast, digestion of

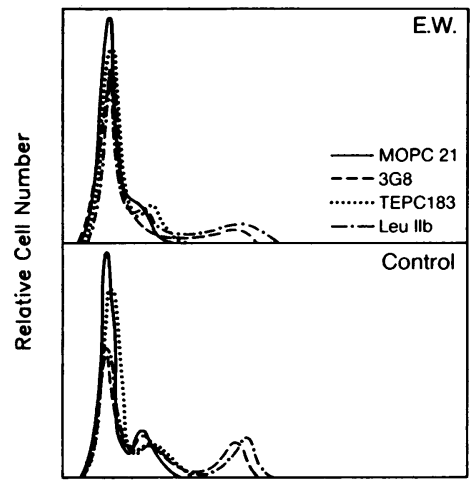

Relotive Fluorescence Intensity (Log)
Figure 4. Peripheral blood mononuclear cells from patient E.W. express Fc $\gamma$ RIII. A small population of mononuclear leukocytes from patient E.W. (presumably NK cells) reacted with MAbs 3G8 and Leu $11 \mathrm{~b}$, as did a small population of mononuclear cells from a healthy control donor. Results shown are representative of those obtained in one additional experiment. 


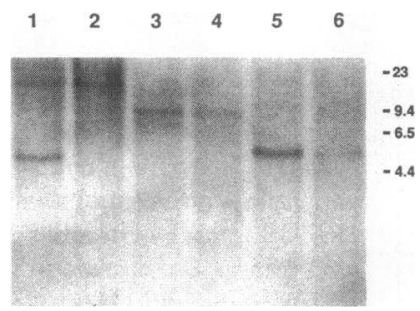

Figure 5. Southern blot analysis of genomic DNA from patient E.W. and a normal control. Genomic DNA from a normal control (lanes 1,3 and 5 ) and the patient (lanes 2, 4 and 6) were digested with Bam HI (lanes 1 and 2), Eco RI (lanes 3 and 4), and Hind III (lanes 5 and 6), electrophoresed in a $1.0 \%$ agarose gel, and blotted to a nylon membrane. The membrane subsequently was probed with a ${ }^{32} \mathrm{P}$-labeled fragment (bases 611-825) of an Fc $\gamma$ RIII cDNA. The migration of DNA fragments of known size (in kb) is shown on the right.

genomic DNA from a healthy control with Bam HI yielded two fragments of $\sim 18$ and $5 \mathrm{~kb}$ which hybridized with the probe, while digestion of the patient's genomic DNA with Bam HI generated only the $18-\mathrm{kb}$ fragment. These results indicate that the NK cell FcrRIII gene in patient E.W. is normal, but that the neutrophil FcyRIII gene probably is not (see Fig. 1). To confirm this, we examined the patient's genomic DNA further for gene-specific sequences.

As expected, using the PCR and synthetic oligonucleotide primers complementary to bases 611-625 and bases 805-825 of the cDNA that encodes neutrophil Fc $\gamma$ RIII, we were able to amplify identical 215-bp fragments from genomic DNA of patient E.W. and the control (Fig. 6). However, whereas all of the fragments amplified from the patient's genomic DNA were susceptible to digestion with Taq I and Dra I, only a portion of those amplified from control genomic DNA were cleaved with these enzymes. These results also indicate that the NK cell FcrRIII gene is normal in patient E.W., but that the neutrophil Fc $\gamma$ RIII gene is not (see Fig. 1).

\section{Discussion}

In the course of examining the structure and function of $\mathrm{Fc}$ receptors on peripheral blood cells of patients with SLE, we identified a patient whose neutrophils did not react with either monoclonal or polyclonal antibodies to Fc $\gamma$ RIII (Fig. 2). Neutrophils from the patient were comparable to neutrophils from healthy controls, however, with respect to their expression of Fc $\gamma$ RII, complement receptor 1, complement receptor 3, and DAF (Fig. 3). Since both DAF and Fc $\gamma$ RIII are anchored to

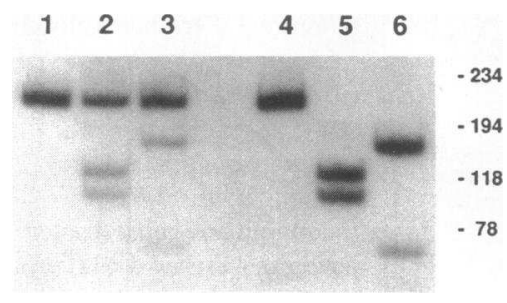

Figure 6. Analysis of gene-specific sequences in amplified fragments of genomic DNA. Fragments of genomic DNA corresponding to a region of the exon that encodes the carboxyterminal portion of Fc $\gamma$ RIII (see Fig. 1)

were amplified in the presence of $\left[{ }^{32} \mathrm{P}\right] \mathrm{dATP}$ (control, lanes 1-3; patient E.W., lanes 4-6), and then analyzed by PAGE and autoradiography before (lanes 1 and 4) and after treatment with either Taq I (lanes 2 and 5) or Dra I (lanes 3 and 6). The migration of DNA fragments of known size (in bp) is shown on the right. the neutrophil plasma membrane via glycosyl linkages to PI (7), it was unlikely that failure of the patient's neutrophils to express Fc $\gamma$ RIII was due to a generalized abnormality involving the formation of PI-glycan linkages. Furthermore, although FcrRIII transcripts were readily detectable in normal neutrophils, we were unable to detect any mRNA in the patient's neutrophils which hybridized with an FcrRIII cDNA (not shown). This finding, as well as the finding that a small population of peripheral blood mononuclear leukocytes (presumably NK cells) from the patient were recognized by antiFc $\gamma$ RIII antibodies (Fig. 4), suggested that the failure of the patient's neutrophils to express FcyRIII was due either to an abnormality involving transcription of the gene that encodes this receptor or to an abnormality involving the structure of the gene.

Although the genes for the neutrophil and NK cell forms of Fc $\gamma$ RIII are highly homologous, there are gene-specific sequences which can be detected with probes complementary to nucleotides in the exon that encodes the carboxy-terminal portion of the receptor (Fig. 1) (4). By examining Southern blots of genomic DNA with such a probe, and by amplifying a region of genomic DNA that contains two gene-specific restriction sites, we found evidence that the neutrophil Fc $\gamma$ RIII gene in the patient is abnormal. Southern blotting of genomic DNA from the patient revealed only those Eco RI, Hind III, and Bam HI fragments that would be expected if the gene that encodes NK cell FcrRIII was intact (Fig. 5). A Bam HI fragment specific for the neutrophil FcyRIII gene was not detected, and no other Eco RI or Hind III fragments were detected to suggest that the neutrophil FcrRIII gene contained only a partial deletion. Furthermore, although the PCR yielded similar 215-bp fragments from genomic DNA of the patient and the control, all of the fragments amplified from the patient's genomic DNA contained the Taq I and Dra I restriction sites that are specific for the NK cell Fc $\gamma$ RIII gene (Fig. 6). In contrast, only a portion of the material amplified from control genomic DNA was susceptible to digestion with Taq I and Dra I, while the remainder (from the neutrophil Fc $\gamma$ RIII gene) was not.

Whereas our results could be explained simply by base substitutions leading to the loss of three restriction sites that are markers for the neutrophil Fc $\gamma$ RIII gene, it is possible that the entire gene is absent or grossly disorganized. The genes encoding for the neutrophil and NK cell forms of Fcy RIII are tightly linked to each other on chromosome $1(4,28)$. Such highly homologous tandem repeats favor intra- and interchromosomal recombination events (29). In particular, a nonreciprocal recombination (i.e., gene conversion) or a reciprocal recombination resulting in a deletion of the neutrophil Fc $\gamma$ RIII gene with or without duplication of the NK cell FcrRIII gene, could account for our findings. Such recombination occurs frequently between the homologous repeats of the $\alpha$-globin gene (30).

Although the abnormality of neutrophil FcrRIII expression described in this report was detected in a patient with SLE, the relation between the abnormality and the patient's disease is not clear. For example, neutrophils from eight other patients with SLE reacted as expected with anti-Fc $\gamma$ RIII antibodies. In addition, despite the inability of her neutrophils to recognize and bind IgG-coated RBCs comparably to normal neutrophils, the patient has not exhibited any unusual susceptibility to bacterial infections. This very likely is due to the fact 
that her neutrophils express normal amounts of Fc $\gamma$ RII and complement receptors, and confirms the important role played by FcrRII in mediating phagocytosis and other responses of neutrophils to encounters with opsonized particles (31-33). Nevertheless, whereas it is likely that the patient's macrophages express Fc $\gamma$ RIII normally, as do her NK cells, it is intriguing to speculate that the abnormality of neutrophil Fc $\gamma$ RIII expression could contribute, at least in part, to abnormal clearance of circulating immune complexes (34-36).

Abnormal expression of Fc receptors on peripheral blood leukocytes has been reported previously. For example, as indicated above, neutrophils from patients with paroxysmal nocturnal hemoglobinuria express reduced amounts of Fc $\gamma$ RIII on their surfaces, along with reduced amounts of other proteins that are anchored to PI (7). In addition, Ceuppens et al. (37) described four healthy individuals belonging to one kindred whose monocytes did not express detectable Fc receptor I. The cells did not bind monomeric IgG and were not recognized by anti-Fc $\gamma$ RI MAbs. To our knowledge, however, this is the first report of an individual whose peripheral blood neutrophils do not express FcrRIII normally.

\section{Acknowledgments}

This work was supported in part by grants from the National Institutes of Health (AR-20684 and HL-19155), the Treadwell Foundation, and the Lupus Foundation of America. Drs. Ory and Clark were supported by an Institutional National Research Service Award (AR-07304).

\section{References}

1. Unkeless, J. C., and S. D. Wright. 1988. Phagocytic cells: Fc and complement receptors. In Inflammation: Basic Principles and Clinical Correlates. J. I. Gallin, I. M. Goldstein, and R. Snyderman, editors. Raven Press, Ltd., New York. 343-362.

2. Unkeless, J. C. 1989. Function and heterogeneity of human Fc receptors for IgG. J. Clin. Invest. 83:355-361.

3. Lanier, L. L., J. J. Ruitenberg, and J. H. Phillips. 1988. Functional and biochemical analysis of CD16 antigen on natural killer cells and granulocytes. J. Immunol. 141:3478-3485.

4. Ravetch, J. V., and B. Perussia. 1989. Alternative membrane forms of FcrRIII (CD16) on human natural killer cells and neutrophils. Cell type-specific expression of two genes that differ in single nucleotide substitutions. J. Exp. Med. 170:481-497

5. Ory, P. A., I. M. Goldstein, E. E. Kwoh, and S. B. Clarkson. 1989. Characterization of polymorphic forms of Fc receptor III on human neutrophils. J. Clin. Invest. 83:1676-1681.

6. Ory, P. A., M. R. Clark, E. E. Kwoh, S. B. Clarkson, and I. M. Goldstein. 1989. Sequences of complementary DNAs that encode the NA1 and NA2 forms of Fc receptor III on human neutrophils. J. Clin. Invest. 84:1688-1691.

7. Selvaraj, P., W. F. Rosse, R. Silber, and T. A. Springer. 1988. The major Fc receptor in blood has a phosphatidylinositol anchor and is deficient in paroxysmal nocturnal haemoglobinuria. Nature (Lond.). 333:565-567.

8. Huizinga, T. W. J., C. E. van der Schoot, C. Jost, R. Klaassen, M. Kleijer, A. E. G. Kr. von dem Borne, D. Roos, and P. A. T. Tetteroo. 1988. The PI-linked receptor FCRIII is released on stimulation of neutrophils. Nature (Lond.). 333:667-669.

9. Scallon, B. J., E. Scigliano, V. H. Freedman, M. C. Miedel, Y-C. E. Pan, J. C. Unkeless, and J. P. Kochan. 1989. A human immunoglobulin $\mathbf{G}$ receptor exists in both polypeptide-anchored and phosphatidylinositol-glycan-anchored forms. Proc. Natl. Acad. Sci. USA. 86:5079-5083.
10. Ueda, E., T. Kinoshita, J. Nojima, K. Inoue, and T. Kitana. 1989. Different membrane anchors of FcrRIII (CD16) on K/NKlymphocytes and neutrophils: protein- vs. lipid-anchor. J. Immunol. 143:1274-1277.

11. Edberg, J. C., P. B. Redecha, J. E. Salmon, and R. P. Kimberly. 1989. Human FcyRIII (CD16). Isoforms with distinct allelic expression, extracellular domains, and membrane linkages on polymorphonuclear and natural killer cells. J. Immunol. 143:1642-1649.

12. Clarkson, S. B., R. P. Kimberly, J. E. Valinsky, M. D. Witmer, J. B. Bussel, R. L. Nachman, and J. C. Unkeless. 1986. Blockade of clearance of immune complexes by an anti-Fc $\gamma$ receptor monoclonal antibody. J. Exp. Med. 164:474-489.

13. Clarkson, S. B., J. B. Bussel, R. P. Kimberly, J. E. Valinsky, R. L. Nachman, and J. C. Unkeless. 1986. Treatment of refractory immune thrombocytopenic purpura with an anti-Fc $\gamma$-receptor antibody. N. Engl. J. Med. 314:1236-1239.

14. Boyum, A. 1968. Isolation of mononuclear cells and granulocytes from human blood: isolation of mononuclear cells by one centrifugation and of granulocytes by combining centrifugation and sedimentation at 1 g. Scand. J. Clin. Lab. Invest. 21 (Suppl. 97):77-89.

15. Fleit, H. B., S. D. Wright, and J. C. Unkeless. 1982. Human neutrophil Fcy receptor distribution and structure. Proc. Natl. Acad. Sci. USA. 79:3275-3279.

16. Perussia, B., G. Trinchieri, A. Jackson, N. L. Warner, J. Faust, H. Rumpold, D. Kraft, and L. L. Lanier. 1984. The Fc receptor for IgG on human natural killer cells: phenotypic, functional, and comparative studies with monoclonal antibodies. J. Immunol. 133:180-189.

17. Looney, R. J., D. H. Ryan, K. Takahashi, H. B. Fleit, H. J. Cohen, G. N. Abraham, and C. L. Anderson. 1986. Identification of a second class of IgG Fc receptors on human neutrophils. A 40-kD molecule also found on eosinophils. J. Exp. Med. 163:826-836.

18. Kinoshita, T., M. E. Medof, R. Silber, and V. Nussenzweig. 1985. Distribution of decay-accelerating factor in the peripheral blood of normal individuals and patients with paroxysmal nocturnal hemoglobinuria. J. Exp. Med. 162:75-92.

19. Changelian, P. S., R. M. Jack, L. A. Collins, and D. T. Fearon. 1985. PMA induces the ligand-independent internalization of CR 1 on human neutrophils. J. Immunol. 134:1851-1858.

20. Wright, S. D., P. E. Rao, W. C. Van Voorhis, L. S. Craigmyle, K. lida, M. A. Talle, E. F. Westberg, G. Goldstein, and S. C. Silverstein. 1983. Identification of the C3bi receptor of human monocytes and macrophages with monoclonal antibodies. Proc. Natl. Acad. Sci. USA. 80:5699-5703.

21. Lalezari, P. 1984. Granulocyte antigen systems. In Immunohaematology. C. P. Engelfreit, J. J. van Loghem, and A. E. G. Kr. von dem Borne, editors. Elsevier Science Publishers B.V., Amsterdam. 33-44.

22. Bell, G. I., J. H. Karam, and W. J. Rutter. 1981. Polymorphic DNA region adjacent to the $5^{\prime}$ end of the human insulin gene. Proc. Natl. Acad. Sci. USA. 78:5759-5763.

23. Simmons, D., and B. Seed. 1988. The Fc receptor of natural killer cells is a phospholipid-linked membrane protein. Nature (Lond.). 333:568-570.

24. Saiki, R. K., D. H. Gelfand, S. Stoffel, S. J. Scharf, R. Higuchi, G. T. Horn, K. B. Mullis, and H. A. Erlich. 1988. Primer-directed enzymatic amplification of DNA with a thermostable DNA polymerase. Science (Wash. DC). 239:487-494.

25. Low, M. G. 1987. Biochemistry of the glycosyl-phosphatidylinositol membrane protein anchors. Biochem. J. 244:1-13.

26. Haziot, A., S. Chen, E. Ferrero, M. G. Low, R. Silber, and S. M. Goyert. 1988. The monocyte differentiation antigen, CD14, is anchored to the cell membrane by a phosphatidylinositol linkage. $J$. Immunol. 141:547-552.

27. Jack, R. M., and D. T. Fearon. 1988. Selective synthesis of mRNA and proteins by human pheripheral blood neutrophils. J. Immunol. 140:4286-4293.

28. Peltz, G. A., H. O. Grundy, R. V. Lebo, H. Yssel, G. S. Barsh, and K. W. Moore. 1989. Human FcrRIII: cloning, expression, and 
identification of an Fcy receptor chromosomal locus. Proc. Natl. Acad. Sci. USA. 86:1013-1017.

29. Bollag, R. J., A. S. Waldman, and R. M. Liskay. 1989. Homologous recombination in mammalian cells. Annu. Rev. Genet. 23:199225.

30. Higgs, D. R., M. A. Vickers, A. O. M. Wilkie, I.-M. Pretorius, A. P. Jarman, and D. J. Weatherall. 1989. A review of the molecular genetics of the human $\alpha$-globin gene cluster. Blood. 73:1081-1104.

31. Willis, H. E., B. Browder, A. J. Feister, T. Mohanakumar, and S. Ruddy. 1988. Monoclonal antibody to human IgG Fc receptors: cross-linking of receptors induces lysosomal enzyme release and superoxide generation by neutrophils. J. Immunol. 140:234-239.

32. Tosi, M. F., and M. Berger. 1988. Functional differences between the $40 \mathrm{kDa}$ and 50 to $70 \mathrm{kDa}$ IgG Fc receptors on human neutrophils revealed by elastase treatment and antireceptor antibodies. $J$. Immunol. 141:2097-2103.

33. Huizinga, T. W. J., F. van Kemenade, L. Koenderman, K. M. Dolman, A. E. G. Kr. von dem Borne, P. A. T. Tetteroo, and D. Roos. 1989. The $40-\mathrm{kDa} \mathrm{Fc} \gamma$ receptor (FcRII) on human neutrophils is es- sential for the IgG-induced respiratory burst and IgG-induced phagocytosis. J. Immunol. 142:2365-2369.

34. Frank, M. M., M. I. Hamburger, T. J. Lawley, R. P. Kimberly, and P. H. Plotz. 1979. Defective reticuloendothelial system Fc-receptor function in systemic lupus erythematosus. N. Engl. J. Med. 300:518-523.

35. Hamburger, M. I., T. J. Lawley, R. P. Kimberly, P. H. Plotz, and M. M. Frank. 1982. A serial study of splenic reticuloendothelial system Fc receptor functional activity in systemic lupus erythematosus. Arthritis Rheum. 25:48-54.

36. Parris, T. M., R. P. Kimberly, R. D. Inman, J. S. McDougal, A. Gibofsky, and C. L. Christian. 1982. Defective Fc receptor-mediated function of the mononuclear phagocyte system in lupus nephritis. Ann. Intern. Med. 97:526-532.

37. Ceuppens, J. L., M. L. Baroja, F. Van Vaeck, and C. L. Anderson 1988. Defect in the membrane expression of high affinity $72-\mathrm{kD}$ Fc $\gamma$ receptors on phagocytic cells in four healthy subjects. J. Clin. Invest. 82:571-578. 